\title{
DAS “TERRAS DE DONOS” ÀS “TERRAS LIVRES”: registros da reprodução camponesa e da luta pela terra na região do Bico do Papagaio
}

\section{FROM "LANDS OF OWNERS" TO "FREELANDS": records of peasantry production and struggle for land in the Bico do Papagaio region}

\author{
Mayka Danielle Brito Amaral \\ Universidade Federal do Maranhão, Curso de Licenciatura em Ciências Humanas, \\ Bacabal, MA, Brasil \\ mbritoamaral@yahoo.com.br
}

\section{Resumo}

Este trabalho tomou como referência empírica de análise a região do Bico do Papagaio. Trouxe registros da reprodução camponesa e da luta pela terra realizada por famílias, que tem o coco babaçu como uma das principais fontes de renda. A polifonia das vozes dos sujeitos constitui a principal fonte dos dados aqui apresentados, os quais foram coletados por meio de pesquisas de campo realizadas entre os anos de 2014 e 2017. A pesquisa mostrou as experiências dos conflitos por terra, destacando as trajetórias das famílias, a importância do babaçu no processo de reprodução social, as estratégias de resistência camponesa e o protagonismo das mulheres nas frentes de luta, nas décadas de 1950 a 1980.

Palavras-chave: Reprodução Camponesa. Luta pela Terra. Resistência. Protagonismo das mulheres. Região do Bico do Papagaio.

\begin{abstract}
This work was based on na empirical analysis the Bico de Papagaio region. It brought records of peasantry production and the struggle for land by families, which has babassu coconut as one of the main sources of income. The polyphony of the subjects' voices is the main source of the data presented here. They were collected through field research conducted between 2014 and 2017. The research showed the experiences of conflicts over land, highlighting the trajectories of families, the importance of babassu in the process of social reproduction, strategies of peasant resistance and women in the fight fronts, in the decades of 1950 to 1980 .
\end{abstract}

Keywords: Peasantry Production. Struggle for Land. Resistance. Protagonism of Women. Bico de Papagaio region.

Introdução

A região do Bico do Papagaio compreende áreas geográficas dos estados do Pará, do Maranhão e do Tocantins definida a partir da concentração histórica dos conflitos 
socioterritoriais na Amazônia brasileira (SADER, 1986; CHAVES, 2015). Nesse sentido, o presente artigo traz registros importantes sobre a reprodução camponesa e a luta pela terra de famílias da área, que têm no coco babaçu uma das suas principais fontes de renda ${ }^{1}$.

O objetivo deste texto é desvelar sobre a reprodução camponesa e a luta pela terra, destacando as trajetórias das famílias, a importância do coco babaçu no processo de reprodução social, as estratégias de resistência camponesa e o protagonismo das mulheres nas frentes de luta nas décadas de 1950 a 1980.

Parte-se do pressuposto de que a sociedade está dividida em classes sociais, que lutam entre si, em seu processo de reprodução (MARTINS, 2002; OLIVEIRA, 1996; BOMBARDI, 2004, 2005), assim, os conflitos socioterritoriais expressam a luta das classes pela terra e pelo território ou frações territoriais (CHAVES, 2015).

$\mathrm{O}$ conceito de conflitos socioterritoriais adotado neste artigo fundamenta-se na tese de doutorado de Chaves (2015) intitulada Rebeldia e barbárie: conflitos socioterritoriais na região do Bico do Papagaio, a partir das elaborações teóricas de Fernandes (2005), o qual se preocupou com a construção de um referencial capaz de compreender os movimentos sociais numa perspectiva geográfica.

Com essa preocupação cunhamos os conceitos que nos possibilitam compreender as ações dos movimentos socioespaciais e dos socioterritoriais, a partir dos espaços e dos territórios construídos pelas relações sociais, materiais e imateriais. Enfatizando, é preciso compreender as formas de organização dos movimentos, tomando como referência, o espaço, o território e o lugar produzidos por suas ações por meio das relações sociais. (FERNANDES, 2005, p. 7).

Nesse sentido, Chaves (2015) entende que os conflitos socioterritoriais consistem nas lutas e ações de ocupação e retomada de terras por movimentos socioterritoriais, isto é, àqueles que “(...) têm o território não só como trunfo, mas este é essencial para a sua existência" (FERNANDES, 2005, p. 7).

Assim, pode-se inferir que a região do Bico do Papagaio é representativa, já que consiste em uma região onde a "questão camponesa" coloca-se como central, considerando a história de luta e resistência contra as ofensivas da classe burguesa.

Os dados registrados neste artigo são frutos de pesquisas de campo realizadas na área de estudo em diferentes momentos no período de 2014 a 2017, quando foram realizadas entrevistas semiestruturadas e livres com os membros das famílias. As falas dos sujeitos constituem a principal fonte de informações. A descrição, rica em detalhes, 
Das "terras de donos" às "terras livres": registros da reprodução camponesa e da luta pela terra na região do Bico do Papagaio

contribui para pôr em relevo situações de conflitos e violências muitas vezes ocultadas nos registros oficiais ${ }^{2}$.

\section{"Situando o caldeirão": a chegada dos camponeses-posseiros}

A chegada das famílias camponesas e dos diversos trabalhadores rurais às terras da região do Bico do Papagaio está relacionada com os conflitos fundiários ocorridos no Brasil entre as décadas de 1950 e 1960. Nesse período, a questão agrária é posta em relevo por questões internas e externas ao país (BOMBARDI, 2005), já que, internamente, viviase a eclosão de diversas lutas camponesas em resistência ao processo de apropriação da terra pelos fazendeiros e empresas capitalistas.

Externamente, no contexto da mundialização do capital marcado pela Guerra Fria, o Brasil assumiu uma postura favorável aos interesses dos Estados Unidos, repercutindo diretamente na sua dinâmica interna, com a elaboração de políticas públicas alinhadas aos interesses do capital (BOMBARDI, 2005). Desse modo, a construção do território brasileiro seguiu as diretrizes da construção do próprio território capitalista no país, o que não foi realizado sem luta e resistência.

Alinhado ao processo de mundialização do capital sob a hegemonia dos Estados Unidos, o governo brasileiro norteou as políticas públicas voltadas para a Amazônia. Vista como um "espaço vazio", as políticas de ocupação foram tomadas como medidas de segurança nacional e como alternativa para "resolver" os conflitos fundiários que ocorriam em outras áreas (OLIVEIRA, 1991).

Os conflitos no campo são uma expressão da luta de classes no processo de construção do território capitalista, pois é a resistência de classe ao avanço do capital, embora ocorrido em contextos diversos, têm elementos comuns. Como uma classe social, contraditoriamente, de dentro do modo de produção capitalista, os camponeses lutam pela liberdade e autonomia para controlar o seu processo de reprodução na terra e o território (MARTINS, 1986).

Compreende-se o território à luz de Oliveira (2013), que o define como uma:

síntese contraditória, como uma totalidade concreta do processo/modo de produção/distribuição/circulação/consumo e suas articulações e mediações supraestruturais (políticas, ideológicas, simbólicas etc.) em que o Estado desempenha a função de regulação. O território é assim produto concreto da luta de classes travada pela sociedade no processo de produção de sua existência. (OLIVEIRA, 2013, p. 74). 
Por isso, a luta de classes é um elemento essencial do processo de reprodução do campesinato no Brasil e na região do Bico do Papagaio, afinal, o deslocamento dos camponeses e trabalhadores rurais do Nordeste para a Amazônia estava dentro do contexto da reforma agrária proposta pelo governo brasileiro após o golpe militar. A partir da questão agrária brasileira, Martins (1985) assevera que essa região foi:

[...] incorporada à situação social e à estrutura de relações sociais, econômicas e de poder que constituem a base contemporânea das lutas camponesas no Brasil. E é nesse sentido que, no meu entender, as lutas pela terra na Amazônia não são corretamente entendidas se analisadas separadamente das lutas pela terra que ocorrem em todas as regiões do país. Há fatores específicos, regionais, de fronteira agrícola, nas lutas camponesas da Amazônia que, no entanto, não estão divorciadas das lutas camponesas do país inteiro. A questão da Amazônia é, em parte, a manifestação regional da questão agrária, uma questão, por sua vez, tecida pelo processo de reprodução do capital, pelo processo de apropriação da renda fundiária pelo capital. (MARTINS, 1985, p. 33-34).

As políticas de ocupação dos "espaços vazios" da Amazônia foram implementadas sem considerar a dispersa ocupação empreendida pelos povos indígenas. Nos estados do Maranhão e Pará, cabe ressaltar, verifica-se a existência e resistência dos quilombolas e camponeses que ocupavam as terras interioranas desde o período da escravidão e do extrativismo da borracha e da castanha (ALMEIDA, 2008).

As famílias de camponeses-posseiros e trabalhadores rurais migraram do Nordeste, especificamente dos estados do Maranhão, do Piauí e do Ceará, em busca de terra sem dono, como uma expressão da negação do "cativeiro" da "terra de dono", a migração significava o caminho para a libertação.

Cansados da exploração a que estavam submetidos nas "terras de donos", sem a perspectiva de mudança, bem como a ocorrência da "seca" do Nordeste, as famílias partiram dos seus lugares de origem, esses motivos foram apresentados pelos camponeses e camponesas entrevistadas.

Em depoimento, o entrevistado A contou que em 1952, quando os seus pais se casaram no estado do Maranhão, o então estado de Goiás surgiu como uma esperança para aqueles que trabalhavam em "terras de donos", e que sofriam com a situação da "seca" no Nordeste. Famílias conhecidas já tinham partido e encontrado abundância de terras livres, devolutas, isso os estimulou a migrarem também.

Em 1958, a família do entrevistado A chegou às terras do povoado São Miguel, município de Itaguatins, antigo estado do Goiás, atual município de São Miguel do 
Tocantins (TO) e encontrou a terra devoluta. Nesse ano, também chegaram mais quatro famílias, todas colocavam roças livremente e assim garantiram a reprodução social por um período de dez anos, até por volta de 1968, quando a "chegada do estranho", como diz Martins (1993), foi anunciada, representada pela chegada dos fazendeiros vindos do Sul e do Sudeste do país.

Nesse período, entre as décadas de 1950 e 1960, Ianni (1979, p. 15) mostrou que ocorria um processo de "reforma agrária espontânea" na Amazônia Legal, isto é, uma "reforma agrária de fato" realizada pelos camponeses-posseiros e trabalhadores rurais, que buscavam por seus próprios meios as soluções para os problemas decorrentes da falta de terra livre para produção e, concomitante, para reprodução da vida.

À margem dos principais interesses políticos e econômicos do país, os camponesesposseiros formavam correntes migratórias para a região do Bico do Papagaio, muito antes do despertar do Estado e do capital. Em períodos de seca no Nordeste, acompanhando os cursos dos rios, migravam, ocupavam áreas próximas das matas e praticavam a "agricultura migratória" (ANDRADE, 2005, p. 234), ou seja, ao encontrar as terras devolutas, roçavam a mata e plantavam. No ano seguinte, deixavam a terra "enfraquecida" descansando e migravam para roçar outra área.

Dessa maneira, diversas famílias partiam em busca da "terra de trabalho". Os camponeses da região do Bico do Papagaio partiram de outros estados, passando por diversos povoados até "situarem o Caldeirão", como afirmou o entrevistado A. Chegaram à região no contexto da realização da "reforma agrária espontânea, de fato", definida por Ianni (1979, p. 21). Pelas veredas entre as matas, com os seus poucos pertences, caminharam por longas distâncias até chegarem ao local onde situaram morada.

Na porção maranhense do Bico do Papagaio, a família da entrevistada B foi uma das pioneiras a situarem a área.

Pois é, quando eu cheguei aqui eu tinha 3 anos de idade. Eu era muito pequena, não lembro, mas a minha mãe conta que a gente vinha até Coquelândia de carro, é um povoado próximo, daqui lá é uns 15 quilômetros, e de lá pra cá a gente vinha montado em animal, numa vereda, que não tinha estrada, era nas veredas. Nós morávamos no município de Caxias aqui no Maranhão. E ai o meu pai falava que pra cá tinha muita mata pra trabalhar de roça, e ai pensando em melhorar, porque lá onde morava, o inverno era muito fraco (néra, mãe?) e aqui chovia muito, e diz que dava muita lavoura, tinha muito coco. E aí todo mundo se animou pra vir para cá. (Entrevistada B, em 27 de fevereiro de 2015). 
Das "terras de donos" às "terras livres": registros da reprodução camponesa e da luta pela terra na região do Bico do Papagaio

Em 1963, quando as famílias chegaram às terras maranhenses, a rede rodoviária era limitada. Nesse período, a estrada recém-criada pretendia ligar o município de Imperatriz (MA) ao Rio Guamá (PA) (ASSELIN, 1982), e serviu de porta de entrada para as terras do interior, onde construíram casas e fizeram roças. Fixavam-se em determinadas áreas, e, aos poucos, com a chegada de mais migrantes, constituíam povoados localizados às margens da estrada.

A construção da rodovia Belém-Brasília contribuiu para o povoamento das terras do interior, pois representou um marco transformador na vida das famílias camponesas na região do Bico do Papagaio e de todo o país.

Assim, a integração Norte-Sul do território brasileiro ganhou grande impulso, acompanhada pela expansão do capital, uma vez que até a construção, o eixo econômico regional estava localizado às margens dos Rios Tocantins e Araguaia, utilizados como principais vias de acesso às terras pelas correntes migratórias, e onde surgiram os principais núcleos urbanos como entrepostos comerciais e povoados (VALVERDE, 1967). Posteriormente, esse eixo foi deslocado para as margens da estrada.

Os moradores mais antigos do povoado A vieram trabalhar na extração da castanha, à medida que as famílias chegavam, ocupavam as áreas e formavam os povoados e trabalhavam na extração da castanha, na produção do babaçu e nas roças.

A família da entrevistada $\mathrm{C}$, uma das mais antigas do povoado $\mathrm{A}$, ocupou primeiramente terras de outro povoado. Os seus pais nasceram no Piauí, e migraram para a região do Bico do Papagaio, em 1956. O pai veio primeiro, após dois anos, trouxe os demais. Veio para trabalhar na extração da castanha, num castanhal localizado próximo ao povoado. A família se deslocou para as terras do povoado A em 1973. O seu tio situou o local, nomeando-o com o seu próprio sobrenome.

A entrevistada A contou que, diante do processo de grilagem das terras do antigo povoado, seu pai acionou o tio para ocupar uma área devoluta. As terras do antigo povoado foram griladas pelos fazendeiros mineiros, baianos e capixabas que chegavam pela rodovia Belém-Brasília recém-criada.

A ação de grilagem foi intensificada, gerando conflitos que resultaram em grandes atos de violência e expulsão dos posseiros (ASSELIN, 1982).

Ao chegarem às terras, nem sempre os camponeses-posseiros as encontravam completamente livres. Em alguns casos, estavam ocupadas pelos índios, o que ocasionava 
guerras para expulsá-los, mas, em outros, conseguiam estabelecer uma relação mais pacífica. As terras do primeiro povoado ocupado pela família da entrevistada $\mathrm{C}$ é o mais antigo da porção maranhense do Bico do Papagaio (ASSELIN, 1982) e, para situarem o local, os camponeses conseguiram que os índios desocupassem a área sem matança e até receberam ajuda no processo de criação e colheita da mandioca.

Sader (1986) assevera que havia um acordo entre os índios e os moradores, onde os índios ficariam concentrados na porção leste. Porém, seis anos depois, essa área foi ocupada por outros posseiros, e transformada em novos povoados e os índios foram expulsos.

\section{A formação dos povoados e a reprodução camponesa}

Após a expulsão dos índios, tanto os camponeses-posseiros como os novos migrantes, dentre eles fazendeiros e empresários, passaram a usufruir dos recursos naturais das terras ocupadas. Asselin (1982) ressalta que havia uma disputa pela apropriação e controle do castanhal dos indígenas, localizado à beira do Rio Tocantins, onde havia a concentração de povoados camponeses.

Os povoados foram se constituindo como unidades territoriais por meio da solidariedade tecida entre os camponeses e com forte presença da Igreja na dinâmica cotidiana, nas lutas e nas relações estabelecidas com os agentes externos (SADER, 1986).

Os povoados visitados na região do Bico do Papagaio são unidades territoriais formadas a partir das inter-relações entre os sítios camponeses, mediante relações de parentesco, vizinhança e pelo sentimento de pertencimento e que têm início desde a chegada dos camponeses a terra.

A consolidação dessas unidades ocorreu a partir das lutas entre as famílias e os fazendeiros grileiros, apoiados pelas autoridades governamentais. A resistência e as lutas camponesas fortaleceram as inter-relações entre as famílias e garantiram a conquista da terra nos povoados $\mathrm{C}$ e $\mathrm{D}$, mas os camponeses dos povoados $\mathrm{A}$ e B não a conquistaram no mesmo período dos anteriores ${ }^{5}$.

Antes da constituição dos povoados como unidades territoriais, os camponesesposseiros se fixavam em "centros", , onde faziam as casas e as roças, desenvolviam laços afetivos entre as famílias e, em muitos casos, já chegavam com esses laços firmados desde os seus locais de origem, isso contribuía para permanecerem próximos e firmarem 
múltiplas relações de reciprocidade entre si, desenvolvendo atividades por meio de práticas de cooperação e ajuda mútua, como assevera Almeida (2008).

A produção camponesa era realizada nos "centros", em forma de "pousio", ou seja, enquanto cultivavam uma área, a outra ficava reservada para o futuro, quando a primeira entrasse em estado de recuperação ${ }^{7}$.

A produção dos povoados visitados baseava-se nos cultivos da roça e no extrativismo do babaçu, além disso, as famílias produziam arroz, feijão, fava, milho, mandioca, macaxeira e batata para o consumo, os produtos que não produziam eram comprados com a renda do coco babaçu.

O extrativismo do coco babaçu é uma atividade praticada pelas famílias camponesas por várias décadas, e passada de geração a geração. Com a transformação da terra em mercadoria em seus locais de origem, as famílias sobreviviam sob a condição de agregados num sistema de parceria com os donos da terra, praticando a coleta do produto. Para permanecerem na terra, uma parte dos cultivos da roça e do babaçu deveria ser entregue aos donos, caso contrário, seriam expulsos, como demonstram os depoimentos coletados.

Até aproximadamente 1950, as famílias camponesas estavam subordinadas ao poder das oligarquias regionais e locais, dos coronéis e grandes proprietários de terras. As relações de trabalho se constituíam por meio das formas tradicionais de dominação pessoal, pois prevalecia uma ordem social pautada no princípio de reciprocidade, na lógica do favor, da generosidade e no "sistema de camaradagem", como destacou Marques (2000).

O depoimento da entrevistada D revela a situação de subordinação a qual muitas famílias estavam submetidas. Nascida em Colinas, no Maranhão, chegou ao povoado B, em 1970. Veio com quatro filhos, e grávida do quinto, acompanhando o seu marido na busca de terra para trabalhar sob melhores condições. Deixou os pais em Colinas (MA), onde aprendeu quebrar coco babaçu com a mãe. A família trabalhava na roça e na quebra do coco, e só podiam vender para o dono da terra.

Ela vendia para os patrões, porque não podia vender para fora. Nesse tempo lá, tinha os agentes e as terras eram do velho SM, não sei se você já ouviu falar. SM. era o dono de lá, ele era rico. Aí, eles botavam os agentes no povoado para comprar coco, farinha, essas coisas, igual a um comércio. Aí, nós vendíamos só para ele, porque não podia vender para fora de jeito nenhum. [E se vendesse para fora?] Tinha que sair de lá... Esse homem ainda tinha os três dias de lei: os três dias de lei que ele fazia. O velho SM botava os trabalhadores para trabalhar três dias de graça nos campos dele lá, e o morador tinha que ir, ou 
então, saia do lugar e perdia a casa e perdia tudo. [E vocês faziam roça na terra dele?] Fazíamos roça. Não podia tirar nem um palmito de uma palmeira, porque se ele soubesse, ia ser preso mesmo! Era igual aos escravos nesse tempo. Se nós morássemos aqui, e aqui fosse município de lá, por exemplo, se nós pegássemos uma farinha ou um coco e vendesse para outro município. [E como a sua mãe foi parar lá nessa terra?] A mãe dela ganhou eles para lá. Ela nasceu e se criou para lá. Lá ela casou, teve família (que éramos nós: éramos nove irmãos... Éramos, agora já morreu). [Então a mãe da sua mãe já morava nessa terra?] Já, já morava lá nessa terra. [E a mãe da sua mãe quebrava coco também] Quebrava. Lá as mulheres todinhas eram quebradeiras de cocos e trabalhadoras 'de' roça, fiavam roupas de algodão também. O meu pai, ele era assim: ele comprava roupas para os filhos de ano em ano na safra do algodão. Nós pegávamos algodão e ele ia vender num local distante e comprava roupa para nós. [E esse algodão era feito onde? Essas roupas? Essa fiação]. A fiação era feita em casa com algodão. Minha mãe ia para o mato quebrar coco e nós meninas ficávamos em casa descaroçando o algodão com o descaroçador, uma de um lado e outra do outro, igual um moedor de cana (risos). Aí, nós descaroçávamos o algodão, pegávamos o álcool, abríamos o algodão todinho e quando ela chegava ela ia bater o algodão de manhã bem cedo. $5 \mathrm{~h}$ era o que a gente escutava lá onde nós morávamos: as mulheres batendo algodão. Ela batia o algodão e dizia: 'Quando eu chegar, eu quero esse algodão todinho estirado'. Aí, eu cortava, pegava o algodão todinho, fazia as tiragens e enchia os 'balainhos' de algodão e quando ela chegava ia fiar: Fazia rede, varanda. Minha avó fazia muita varanda na almofada, tinha os bilros dela fazer e as roupas meus pais compravam os tecidos e pagavam para fazer (...). (Depoimento cedido pela entrevistada D, em 12 de outubro de 2016) ${ }^{8}$.

A situação de subordinação e exploração das famílias camponesas pelos fazendeiros latifundiários ocorria nas "terras de dono", segundo a entrevistada D. Uma condição de "cativeiro", que ela associa ao trabalho escravo, pois não tinham liberdade de acessar a terra e os seus recursos naturais, nem tão pouco controlar a produção e a comercialização dos produtos. Somado a isso, ainda tinham a obrigação de trabalhar três dias grátis nas terras do fazendeiro, sob pena de serem expulsos e perderem a casa e demais pertences.

Outro ponto relevante no depoimento da entrevistada $\mathrm{D}$ refere-se à quebra do coco babaçu, que há muito tempo tem sido uma importante fonte de renda das famílias, para a compra dos produtos que não produziam. Mesmo no contexto da restrição imposta pelo dono da terra, proibindo a venda dos cocos para outros, a família garantia o mínimo para a sua sobrevivência. A reprodução camponesa era realizada por meio do trabalho na roça, na quebra do coco e da coleta do algodão, com a renda sendo extraída pelo dono da terra sob a condição de extrema exploração.

Além disso, o depoimento da entrevistada D é expressivo também para entender a migração como uma estratégia de libertação e resistência ao "cativeiro da terra" nos locais de origem das famílias camponesas. Quando a família não migrava em conjunto, à medida 
que os filhos cresciam e constituíam novas famílias acabavam migrando. A entrevistada D se casou e acompanhou o seu marido, enquanto os seus pais continuaram em Colinas (MA). Diferente da família do entrevistado A, que migrou em conjunto depois da notícia sobre a abundância de terras livres no então estado de Goiás, como referido anteriormente.

Sader (1989) chama atenção que o significado da migração das famílias camponesas para a região do Bico do Papagaio, deve ser buscado:

[...] na luta desse campesinato pela manutenção da sua identidade e de sua reprodução enquanto produtor direto, conservando traços importantes de um sistema de cultura, hoje em vias de desaparição pela privatização crescente das terras nas áreas ditas de "fronteira agrícola". (SADER, 1989, p.1).

Ao chegar às terras devolutas, sem a presença dos patrões, a esperança da liberdade e autonomia para garantir a reprodução fortaleceu as unidades familiares. O sentido da produção camponesa é garantir a reprodução da própria família, diferente da produção capitalista que visa à acumulação 9 .

Libertando-se das diferentes formas de subordinação e exploração nas terras de dono, ao chegar às terras livres, as famílias passaram a produzir para o autoconsumo, produziam mercadorias para serem trocadas por outras mercadorias que não produziam. A região do Bico do Papagaio representou um "eldorado" para as famílias, considerando a situação de escassez em que viviam. Encontraram terras livres, com recursos naturais em abundância. Era o início de uma nova fase na trajetória de vida, uma fase de liberdade e fartura para os camponeses da região do Bico do Papagaio.

A entrevistada E, mãe da entrevistada B, tem 74 anos, nasceu no estado do Piauí, migrou primeiramente para as terras do interior do município de Caxias (MA), posteriormente, partiu para a região do Bico do Papagaio. Migrou "porque aqui tinha muita terra para a gente trabalhar, e lá já estava difícil, dificuldade, e para cá era melhor para trabalhar, para sobreviver". E quando chegou, na década de 1960, obteve muita fartura com a produção do arroz.

Era a primeira roça de palha de arroz, que tinha plantado. Estava na palha de arroz ainda. Era bom para trabalhar, aqui nós tínhamos fartura. O meu marido botava uma roça mulher, a gente colhia tanto arroz, feijão, abóbora, milho, tudo, mandioca, batata, inhame, nós fazíamos fartura. Era só para alimentação, ai aquele arroz tirava da despesa do ano e o outro ele vendia para fazer o rancho, comprar roupa, rede, carne, essas coisas que precisava. (Depoimento cedido pela entrevistada E, em 09 de dezembro de 2016). 
Era o tempo da fartura da roça e também do coco, eles podiam realizar o extrativismo do babaçu livremente, tirar o azeite para cozinhar e fazer sabão, além de construir suas próprias casas com as palhas da palmeira.

A coleta do babaçu poderia ser realizada pela família ou por grupos de famílias dos povoados. No âmbito da unidade familiar, no período de entressafra da roça, a camponesa-quebradeira saía para as matas coletando coco. Juntavam e levavam para o quintal da casa, para quebrar. A atividade não era genuinamente feminina, os homens também quebravam. Em grupo, as mulheres do povoado se reuniam para coletar e quebrar. Deixavam as crianças mais velhas cuidando da casa e das crianças menores e saiam com as outras companheiras para trabalhar.

Nessa época, a prática do "adjunto do coco" era comum entre as mulheres. $\mathrm{O}$ ajunto é o nome dado à prática do mutirão realizada pelas camponesas-quebradeiras de coco. Reuniam um grupo de mulheres para quebrar para uma delas, posteriormente, a dona do ajunto deveria quebrar a mesma quantidade para as participantes, como forma de pagamento.

Assim como as terras dessa região surgiram como um "eldorado" de riquezas naturais para as famílias camponesas, capaz de libertá-las do "cativeiro" das "terras de dono", também tiveram essa conotação para os "homens de negócios" de outras regiões. Ao mesmo tempo em que novos camponeses, lavradores, buscavam as terras para a sobrevivência, esses "homens" a enxergaram como uma forma de enriquecimento rápido e fácil (ASSELIN, 1982).

Como a lógica da produção camponesa é fundamentada na produção e reprodução da própria existência, sem vislumbrar a acumulação, tal como ocorre na lógica da produção capitalista, os camponeses não se preocuparam com a titulação da terra. Tomando-a como um bem natural, produziam sem demarcá-las dentro das normatizações do Direito Constitucional. Tinham uma concepção diferente da dos novos migrantes. Estes já vieram para a região com a intenção de acumular, isto é, de construir grandes patrimônios, seja por meio da especulação ou da exploração dos bens naturais.

Com a transformação da terra em mercadoria, os camponeses iniciaram mais uma fase tensa na história de suas vidas. Por meio dos "cercamentos", muitas famílias ficaram à margem das cercas e das estradas. Era o fim da "terra liberta". Muitos camponeses foram 
expulsos, outros permaneceram sob a condição de parceiros (meeiros), peões das fazendas, e com a quebra de coco babaçu.

Embora a terra estivesse cercada, as camponesas continuaram extraindo coco babaçu, atividade fundamental no processo de reprodução das unidades familiares. A entrevistada $\mathrm{F}$ narra com orgulho o trabalho que realizava com o marido, para criar os filhos e netos.

[...] eu digo que eu não tenho vergonha do que eu fazia, eu quebrava o coco, trabalhava de roça, apanhava o arroz, capinava, plantava mandioca mais meu esposo, ele ficava ali e eu plantando, e nós criamos 10 filhos e três netos na luta, inclusive eu tenho dois netos ainda que eu crio. Ele faltou e eu fiquei lutando, é doído né? Porque nós trabalhávamos juntos. (Depoimento cedido pela entrevistada F, em 07 de dezembro de 2016).

Apesar de trabalharem juntos, praticando a ajuda mútua nas diversas atividades da unidade familiar, no geral, havia uma divisão interna do trabalho. Ao amanhecer, enquanto os camponeses trabalhavam nas roças, as camponesas faziam a coleta e a quebra do coco. A filha mais velha ficava em casa, cuidando das crianças menores. Os filhos e as filhas também podiam ser levados para o mato, para aprenderem as atividades dos pais.

Quando as camponesas levavam as crianças para o mato, estas aprendiam brincando. No meio dos montes de coco, as mães o partiam em quatro bandas, deixando apenas as amêndoas para retirarem. A brincadeira era uma forma de introduzir as crianças ao "universo" camponês e consistia numa forma de socialização das crianças no interior da divisão de trabalho da família (TAVARES DOS SANTOS, 1978).

As camponesas-quebradeiras de coco da região do Bico do Papagaio identificaram a prática da quebra do coco e os conhecimentos associados a ele como uma "herança" deixada pelos pais. Orgulhosas, agradecem as mães por terem transmitido esse saber. Afirmam que graças a ele, puderam sobreviver e criar os filhos. A entrevistada $F$ foi uma das que fez essa ressalva. Segundo ela,

$$
\begin{aligned}
& \text { [...] lá minha mãe, como era de primeiro, os filhos já endureciam e os pais já } \\
& \text { botavam para começar a trabalhar né, não é igual hoje que tem o estudo e tudo. } \\
& \text { O estudo tinha, mas não era assim. Porque pobre não podia colocar o filho na } \\
& \text { escola, porque era pesado. Não é igual hoje, que tem muita oportunidade, e já } \\
& \text { os filhos da gente não querem. E hoje eu digo assim, que sinto falta da leitura, } \\
& \text { mas na mesma hora eu dou graças a Deus, que minha mãe não me deu a leitura, } \\
& \text { mas me deu o trabalho, porque ela não podia né, era pobre. (Depoimento } \\
& \text { cedido pela entrevistada F, em } 07 \text { de dezembro de 2016). }
\end{aligned}
$$

Ao longo do dia, as crianças aprendiam a prática da quebra do coco e no final da tarde, as camponesas retornavam para a casa com os sacos de amêndoas, e as vendiam 
nos pequenos comércios dos povoados. Muitas vezes, as famílias nem pegavam no dinheiro, apenas as trocavam pelos produtos necessários. As amêndoas eram levadas para a empresa de óleo OVIL (Óleos Vegetais Imperatriz Ltda.), localizada em Imperatriz (MA), onde se concentrava uma parte da produção do babaçu da região do Bico do Papagaio (SADER, 1986).

De acordo com Sader (1986), tanto a produção do arroz quanto a do babaçu estavam submetidas a um "esquema de comercialização" subordinado ao capital mercantil. Considerando a análise da "economia política do babaçu", realizada por Amaral Filho (1990), pode-se afirmar que essas produções estavam subordinadas ao capital comercial e ao capital industrial emergente na região.

No "esquema de comercialização", a figura do "quitandeiro" tinha um papel importante. Poderia ser, entre outros, um camponês, dono de um pequeno comércio, onde vendia produtos de consumo básicos, tais como sal, querosene, pilhas, alguns remédios e produtos de higiene pessoal, para os camponeses. A carência de alimentos foi destacada pelas camponesas quando se referiam à troca do coco por alimentos nos armazéns, todas enfatizaram a importância do coco como um meio de sobrevivência, que impediu a morte de muitas famílias por falta de alimentos.

Com o "cercamento" das terras pelos fazendeiros e grileiros, o extrativismo do babaçu ser tornou mais difícil, pois o coco ficou preso nas "terras de dono". As camponesas dependiam da "boa vontade" do fazendeiro, para deixá-las entrar e coletar. Muitos fazendeiros as proibiam. Porém, diante da carência de alimentos, elas acabavam passando por debaixo das cercas para "roubar" o coco babaçu.

A entrevistada $G$ disse que não viveu esse tempo, mas contou a situação vivenciada por sua mãe.

Ah minha filha, eu não alcancei esse tempo não, não é que eu não
alcancei é porque eu não fazia, mas minha mãe rasgou muito as costas
roubando coco nas fazendas, passando por debaixo de arame escondida
arrastanto saquinho, para botar distância. É como daqui até a casa da
Faustina para o dono da fazenda não escutar nem um barulho de ar.
Minha mãe roubou muito coco para comprar leite para os meus irmãos.
(Depoimento cedido pela entrevistada G, em 08 de dezembro de 2016)
(grifo meu).

Além da mãe da entrevistada $\mathrm{G}$, que teve a costa rasgada ao passar por debaixo do arame das cercas, a entrevistada $\mathrm{H}$ confessou que se sentia humilhada por depender da autorização dos fazendeiros para acessar os babaçuais, uma vez que, quando chegaram à 
região, a terra era devoluta e não tinha "dono". As camponesas coletavam coco livremente.

\begin{abstract}
É, essas que eu estava falando, da gente carregar, era tipo assim uma humilhação, porque quando a gente chegava, e não tinha os fazendeiros, não era assim. A gente chegou num lugar que não tinha fazendeiro ainda. Aonde a gente chegava, juntava, porque quebradeira de coco anda mais que pensamento de jumento. Aonde ela chega aqui, bate os pés no mundo, aqui não é bom e vai caçar outro lugar lá, e aí dificultou muito e assim ficou. Porque tinha que ajuntar, carregar, botar num lugar para fazer a barraca e quebrar. E antes não era assim. Nos princípios não foram assim. Mas aí a gente acostumou e caiu na real, quebrava mesmo, que era o jeito. (Depoimento cedido pela entrevistada H, 07 de dezembro de 2016).
\end{abstract}

A chegada dos fazendeiros, o processo do "cercamento" da terra e, consequentemente, o apresamento do coco sujeitaram as famílias camponesas. Muitos fazendeiros permitiam a coleta do coco, com a condição de que as amêndoas fossem vendidas apenas para eles. Sem terra, as camponesas-posseiras eram obrigadas a se sujeitarem às condições e humilhações impostas pelos fazendeiros.

A partir da pecuarização das terras, os fazendeiros passaram a devastar os babaçuais e dificultar a entrada das camponesas para coletar e quebrar coco. Entretanto, diante da opressão, humilhação e subalternização as quais estavam submetidas entre a cerca e a estrada, as famílias se mobilizaram e buscaram ajuda para resistir e lutar na terra. Não queriam migrar mais uma vez, abrindo mão do "seu lugar", pois reconheceram o direito de permanecer na terra, considerando que foram as pioneiras do seu desbravamento.

\title{
O "cruzamento de arame": resistência e luta pela terra em Juverlândia (TO) e Olho d'água (TO)
}

Como bem destacou Martins (1993), o camponês-posseiro atuou como o grande desbravador das terras da Amazônia Legal. Nesse sentido, compreende-se a dificuldade da entrevistada I, e das demais famílias, em aceitar o processo de expropriação e expulsão perpetrado pelos agentes capitalistas, materializados nos fazendeiros e empresários, com o apoio do Estado.

O processo de ocupação da terra e a formação dos povoados reflete a situação de fronteira, definida por Martins (2009), onde se encontram e desencontram-se movimentos populacionais com diferentes racionalidades, concepções de vida e de mundo, pautados em regimes de propriedades distintos. 
A chegada dos fazendeiros juntamente com os demais agentes da "frente pioneira" provocou intensos conflitos na região do Bico do Papagaio (MARTINS, 1991, p. 67-68). Os "mineiros", assim como eram chamados pelas famílias camponesas, tinham uma racionalidade capitalista, fundada no regime de propriedade privada da terra. Ao adentrála, iniciaram uma "caça aos posseiros" e "uma caça aos índios" (IANNI, 1979) que a ocupavam. As famílias camponesas-posseiras praticavam a posse como regime de propriedade, com uma racionalidade centrada na reprodução da vida, da família, e não da acumulação e da riqueza.

Entre meados das décadas de 1970 e 1980, durante a ditadura militar, as famílias do povoado D e C experienciaram conflitos de terra na região do Bico do Papagaio. Os fazendeiros chegaram demarcando e as proibindo de fazerem roças e extraírem os produtos da floresta. Como não tinham os documentos das terras, sobreviveram sob ameaças, violências, expropriações e expulsões praticadas pelos tais "mineiros", "protegidos" pelos policiais. Camponeses foram torturados e assassinados, assim como padres associados à Comissão Pastoral da Terra, que realizavam trabalho de base junto às populações do campo.

A entrevistada $\mathrm{J}$ contou um pouco sobre o conflito que vivenciaram.

\begin{abstract}
No ano de 80 até 70, por aí assim, eu não lembro do ano direitinho. Na época que mataram o padre Josimo, que foi um padre que deu muito apoio para nós. Foi em 86, isso estava um conflito tão pesado, os nossos maridos saíam pra roça e a gente ficava rezando, pedido a Deus que seguisse os passos dele e trouxesse para casa, para que não morresse na estrada ou lá na roça, no trabalho. Porque teve que morrer companheiro com saco de arroz nas costas que ia plantar e jagunço, pistoleiro matava a mando dos fazendeiros. Diziam que essas terras eram deles, e nós reivindicávamos, dizíamos que essa terra era nossa. Nós chegamos aqui tinha só mata e fera, nós que amansemos aquelas feras, que desbravamos as matas pra trabalhar e ninguém vendeu para eles. A nossa briga foi grande contra eles, contra o dinheiro, contra o poder, essa grande corrupção contra nós. Aí até que padre Josimo viu o nosso sofrimento, ele era um padre que chegou em São Sebastião, aí vendo a história, o nosso grito pedindo socorro e ele tomou as nossas dores né. (Depoimento cedido pela entrevistada J, em 12 de outubro de 2016).
\end{abstract}

Até a chegada dos fazendeiros e pistoleiros, as famílias camponesas tinham liberdade de produzir roças e coletar coco babaçu. Porém, quando chegaram, a entrevistada $\mathrm{J}$ afirma que: "ninguém podia tirar mais nenhum cipó no mato, que estava o jagunço lá no mato com os revólveres, as cartucheiras cheias de bala e proibia a gente de tirar o cipó”. 
Diante das ameaças e das agressões dos fazendeiros, as famílias buscavam a justiça, porém não obtinham respostas favoráveis, pois ela estava aliada aos interesses dos fazendeiros. O apoio principal veio dos padres e freiras que atuavam na região. A entrevistada $\mathbf{J}$ contou que escrevia cartas de denúncia e entregava para o padre e as irmãs, para que levassem às autoridades. Quando isso acontecia, a agressão diminuía, mas depois continuava.

Marques (2000) assevera que a Arquidiocese de Goiânia e a Diocese de Goiás eram comprometidas com as lutas dos camponeses e trabalhadores rurais, e que juntamente com a Prelazia de São Félix do Araguaia e a Prelazia de Marabá, localizadas no Norte do Mato Grosso e no Sul do Pará, formaram um grupo de Igrejas Progressistas atuantes.

Em 1973, os bispos produziram um documento de denúncia da situação agrária na região e a grande miséria a qual as famílias estavam submetidas, convocando a sociedade para lutar por transformações sociais.

A atuação do Pe. Josimo Morais Tavares, tratada na fala da entrevistada $J$ e de outras camponesas entrevistadas, revela o apoio da Igreja à luta pela terra. O padre pertencia à Prelazia do município de Imperatriz (MA), ex-pároco do povoado São Sebastião, no Norte do antigo estado de Goiás, atual Tocantins. Desenvolvia um trabalho de orientação e conscientização política das famílias camponesas, costumava explicar sobre a importância da resistência na terra, afirmando que a produção definia os seus verdadeiros donos, portanto, não deveriam sair, mas permanecerem trabalhando. Lutava pela reforma agrária na região do Bico do Papagaio.

Porém, assim como as famílias camponesas, lideranças, mediadores e apoiadores foram perseguidos, torturados e assassinados. O Pe. Josimo foi um deles, vinha sofrendo ameaças e atentados, e treze dias antes do seu assassinato advertiu as autoridades locais, o Ministério de Justiça e a Anistia Internacional, que corria risco de vida, mas nenhuma atitude foi tomada. Em 10 de maio de 1986, foi assassinado em frente ao escritório da CPT, em Imperatriz (MA) por um pistoleiro contratado por um fazendeiro do estado de Goiás, atual Tocantins (SENHOR, n. 289, 30 ago. 1986).

Além da repressão às manifestações dos camponeses, das expulsões realizadas pelos fazendeiros e pistoleiros, havia também a destruição das roças, ataques, ameaças e torturas. Para se defender, as famílias passaram a trabalhar em mutirão. A entrevistada L falou sobre as roças coletivas, realizadas como estratégia de defesa e resistência. 
Nessa época, nesses anos do conflito, os homens faziam roça. Para fazer a roça para um, tinha que ir 40 homens, era 20 na foice, era 20 e 20 trabalhando para desbravar um pedaço de mata para fazer roça para pessoal. Era muito difícil, foi muito difícil, mas nós vencemos essa causa. Que naquele tempo o juiz de direito só dava direito para os fazendeiros, só dava o direito para aqueles grandes que tinham dinheiro. A polícia vinha também prender, foi muito companheiro preso nessa época aqui no Bico do Papagaio, e foi geral, as comunidades todas. Se tu ver as Sete Barracas, Sete Barracas foi um lugar no conflito tão pesado que até hoje os companheiros têm uma terra coletiva, tiraram um documento só porque não podia trabalhar sozinho, a terra de lá é só uma terra em geral. Quer dizer que se alguém mexer na ponta daquela terra, tá mexendo com a comunidade toda do assentamento. A terra coletiva porque a gente achou, lutou pelo sindicato, aí tinha que fazer aquela terra coletiva para ver se o povo trabalhava junto para evitar de tá morrendo de um a um, um em cada roça, um em cada terreno. (Depoimento cedido pela entrevistada $\mathrm{J}$, em 12 de outubro de 2016).

Segundo Sader (1986), as roças coletivas nasceram no povoado São Pedro d'Água Branca, localizado anteriormente no município de Imperatriz (MA), onde os posseiros enfrentaram conflitos com grileiros. Ao perceberem que eram atacados quando trabalhavam sozinhos na mata, começaram a se organizar em mutirão ${ }^{10}$. Como uma estratégia de defesa e resistência contra a expulsão e invasão dos fazendeiros, as roças coletivas foram adotadas em diversos povoados da região do Bico do Papagaio.

Além das roças coletivas, as famílias usavam outras estratégias de defesa. Em situações de conflito, escondiam-se na mata. As mulheres e as crianças mais velhas ficavam no povoado, esperando que os fazendeiros, os pistoleiros e os policiais fossem embora, para avisarem aos pais. Desde cedo, as crianças foram inseridas na dinâmica do conflito, nas estratégias de defesa das famílias, isso é significativo na lógica que rege a unidade familiar, pautada na ordem moral camponesa, substanciada nos valores, costumes e na própria luta e resistência em defesa de um projeto de vida e de sociedade (BOMBARDI, 2005), assim, se está diante de uma fração do campesinato que não se rendeu à violência, ameaça e prisões.

Após os conflitos, bem como as diferentes formas de enfrentamento, defesa, resistência, algumas famílias tiveram suas terras demarcadas pelo GETAT, outras só conseguiram mais tarde, por meio da criação de projetos de assentamentos pelo Incra (Instituto Nacional de Colonização e Reforma Agrária).

A divisão das terras pelo Incra significou uma conquista para as famílias do povoado C, mas realizou-se de forma autoritária e arbitrária, uma vez que não considerou o ordenamento espacial criado anteriormente. As famílias receberam lotes em áreas distantes do povoado, de 3 a $13 \mathrm{~km}$ de distância, o que dificultou o trabalho cotidiano. 
Para garantir a produção de alimentos da roça e do babaçu, precisavam alternar o tempo entre a casa e o lote. A casa permaneceu no povoado, onde tinham acesso à escola, posto de saúde, mercadinho e maior facilidade de deslocamento para a cidade. No lote, mantiveram as roças com o barraco para quebrar coco. Algumas famílias coletavam coco no lote e levavam para quebrar no quintal de suas casas.

No contexto dos conflitos que envolveram as famílias do povoado $\mathrm{C}$, as do povoado D vivenciaram uma situação diferente em certa medida. A família do entrevistado A morava no povoado e tomava conta de um sítio das freiras nas terras do município. Quando elas foram embora, o pai do entrevistado A o comprou, mas continuou na área do Caldeirão, onde primeiro se situou. Aos poucos, os fazendeiros chegavam, dizendo que eram donos das terras, e as cercaram, expulsando os camponeses da área.

Segundo a entrevistada $\mathrm{M}$, irmã do entrevistado A, a estratégia dos fazendeiros era comprar as casas das famílias, expulsando-as das terras, utilizavam um discurso de melhoria das condições de vida, iludindo-as para que as vendessem. Ao comprarem, passavam a ameaçá-las e expulsá-las.

A família do entrevistado A e a entrevistada M ficou cercada pelos fazendeiros, mas resistiu. A mãe desses entrevistados não aceitou vender as terras e a casa. Sofreu muitas ameaças, ordem de despejo, mas resistiu e foi em busca dos seus direitos junto às autoridades externas ao município.

Lá tinha quatro famílias que andavam juntos, (para) todos os lados que iam, eram essas quatro. $\mathrm{E}$ ao redor tinham mais pessoas, só que as pessoas eram muito nervosas e tinham medo de morrer. Porque quando 'eles' vinham, vinham querendo matar mesmo. Minha mãe teve muitos filhos, ela teve 18 filhos, mas quando chegava a polícia (...), que era comunidade, e dizia nós vamos lá para as terras dos C., o pessoal que conhece a gente (que começou a cidade, o local) dizia assim: 'Olha, vocês vão para lá, mas lá é muita gente! Aquela mulher tem 18 filhos!'. Eram 18 filhos com meu pai e mãe 20 e com minha vó, 21. Quando a polícia chegava lá com os pistoleiros, achavam minha mãe, minha vó e às vezes os meninos pequenos em casa. Eles ficavam com medo e achavam que nós estávamos todos na trincheira, pensando que botávamos trincheiras para pegar eles. Eles não viam ninguém porque estávamos todos trabalhando, fazendo as coisas, um para um lado, o outro para outro, todos jovens. Então, não faziam nada com os três, porque não sabiam onde a gente estava. Enquanto que nós nem estávamos sabendo que 'eles' estavam vindo. Eles pensavam que estávamos ali na trincheira para na hora que acontecesse alguma coisa, pegá-los. Aí não acontecia. O povo dizia: 'Lá é muita gente', mas quando eles chegavam lá não achavam esse povo. Com isso, foi indo até quando a mãe andou, ela foi em Brasília, ela foi no Trinta, tudo atrás dos direitos dela, porque estava muito tempo morando na terra. (Depoimento cedido pela entrevistada M, em 18 de outubro de 2016). 
A linguagem da entrevistada $\mathrm{M}$, ao descrever o conflito, chama atenção para o contexto de guerra vivenciado em toda a região do Bico do Papagaio, tanto na porção do estado do Tocantins, como na do Maranhão e Pará. Além disso, deixa claro em seu depoimento o significado da terra para a família, justamente, a "terra de trabalho", ressaltada por Martins (1993). Enquanto, os agentes do capital e do Estado esperavam uma "trincheira" de ataque, os membros da família estavam trabalhando na produção de alimentos para a reprodução.

É importante destacar ainda o protagonismo da mãe dos entrevistados A e M na busca pelos seus direitos e na luta pela terra. A experiência de escassez nas terras maranhenses deu "força" e estímulo à luta, após sucessivos episódios de subordinação nas "terras de donos", de humilhação, expropriação e expulsão, finalmente a família conseguiu um pedaço de terra.

As experiências de luta pela terra podem ser entendidas como germes da consciência política dos camponeses. Mesmo na ausência de uma organização, sindicatos, que os apoiassem nesse momento, não desistiram.

Ela não tinha muito a quem recorrer. Nesse tempo não tinha ainda nenhuma organização aqui na região. Não tinha sindicato, o que tinha era só a Igreja, mas só que a igreja também não se envolvia muito com essas coisas não porque eles também tinham medo de morrer. É... O pessoal: o padre, o pessoal. Eles nem davam muita orientação sobre essas coisas porque eles também tinham medo porque naquele tempo era o tempo do regime militar, não é? Então, ninguém podia falar muita coisa. Era muito difícil para as pessoas porque qualquer coisa que a gente falasse você ia ser massacrado, por que o regime militar era fogo. Aí, a mãe foi mesmo por conta. Ela não teve muita orientação de ninguém não. Ela foi por conta, por que ela sentiu a necessidade porque quando eles vieram do Maranhão, eles já vieram porque lá não tinha lugar para eles morarem. Lá não tinha terra para eles trabalharem e aí quando chegou aqui ela já começou a trabalhar na terra e já tinha um lugar que ela podia dizer que era dela. De repente, apareceram as pessoas falando que eram donos e ela sentiu a necessidade de lutar e caiu na luta, por que ela tinha os filhos dela para criar e não tinha a quem recorrer, aí ela foi caçar os direitos dela e mais meu pai. Tinha mais uns amigos que sempre andavam juntos, mas nessas viagens longas assim quem ia era ela mais meu pai (Depoimento cedido pela entrevistada M, em 18 de outubro de 2016.). (Grifo meu).

A entrevistada $\mathrm{M}$ revela o nascer dessa consciência política na experiência da sua mãe, quando a família viajava em busca de apoio para permanecerem na terra, pagavam uma taxa ao GETAT. Essa taxa foi paga durante 15 anos. Tinha um documento que comprovava o cadastro da terra junto ao órgão público, o qual foi importante no processo de luta. Até receber o título definitivo da terra, as famílias viviam num clima de terror, ameaça e violência, como descreveu em seu depoimento. 
O entrevistado A disse que, durante doze anos, sobreviveram sob ameaça dos fazendeiros, grileiros, pois eles faziam o cruzamento dos arames, sem respeitar a demarcação realizada pelos camponeses. Cruzavam o arame para tomar parte das terras, causando grandes tensões e também atiravam nas portas das casas para amedrontar as famílias.

Após doze anos sobrevivendo no contexto desses conflitos, em 1985, a família dos entrevistados $\mathrm{A}$ e $\mathrm{M}$ recebeu o título definitivo da terra, expedido pelo Incra. $\mathrm{O}$ entrevistado A relatou que a sua mãe conversou com o Governo do Estado e depois com o Presidente, em Brasília, onde recebeu uma carta autorizando-a permanecer na terra. E, dois meses depois, foram demarcar a sua área.

O importante papel da mãe dos entrevistados A e M na luta pela terra é reconhecido entre os membros da família, a resistência da camponesa garantiu a posse do sítio, comprado das freiras, juntamente com as terras do Caldeirão, que somavam 40ha da família, e para as demais famílias que estavam na luta também. Eram quatro famílias lutando juntas, mas a mãe dos entrevistados A e M era a que saía para lutar pelos direitos, levando consigo os nomes das outras.

\section{Considerações finais}

No período militar, a resistência e luta pela terra no Brasil e na região do Bico do Papagaio foi intensa, com saldos negativos e positivos para as famílias do campo. Nesse período, especificamente no ano de 1979, Martins (1986) chama atenção para os 128 conflitos de terras registrados pela Comissão Pastoral da Terra no estado do Maranhão, dos quais quatro envolviam mais de 1.000 famílias, cada um.

O presente artigo trouxe registros importantes sobre a reprodução camponesa e a luta pela terra na região do Bico do Papagaio, especialmente no período de 1950 a 1980. Por meio das entrevistas adentrou-se ao "universo camponês" e se revelou as trajetórias das famílias da área, a importância do coco babaçu no seu processo de reprodução social, as estratégias de resistência e o protagonismo das mulheres nas frentes da luta.

Os depoimentos das camponesas e dos camponeses revelaram as experiências do conflito como uma expressão da luta de classes nas unidades territoriais dessa região. Narraram os desafios enfrentados para se libertarem do "cativeiro" das "terras de dono" em seus lugares de origem, o processo de construção da vida cotidiana na "nova" terra, a 
Das "terras de donos" às "terras livres": registros da reprodução camponesa e da luta pela terra na região do Bico do Papagaio

chegada dos "homens de negócios" apoiados pelo Estado e suas ações de ameaça, tortura e violência; as formas de resistências empreendidas contra as famílias e as conquistas socioterritoriais que obtiveram.

As famílias desvelaram com detalhes os sentimentos provocados pelas ações dos fazendeiros, dos empresários e do Estado. Durante muito tempo viram a migração como uma alternativa diante dos processos de expropriação e expulsão, porém, decidiram resistir, lutar e conquistar a sua fração territorial.

A decisão de resistir e lutar pela terra estava fundamentada nas experiências sucessivas das migrações vivenciadas pelas famílias. Além disso, as inter-relações estabelecidas nos povoados, a fatura e a autonomia conquistada contribuíram para o fortalecimento dessa posição. E, nesse sentido, o apoio dos padres e das freiras foi importante.

Os depoimentos registrados revelam ainda o protagonismo das mulheres camponesas na luta pela terra e pelo livre acesso aos recursos naturais, especialmente, o coco babaçu. Em diversas situações de conflito, elas estiveram à frente das estratégias de luta, resistência e enfrentamento às ofensivas dos fazendeiros, pistoleiros e dos agentes do Estado. $\mathrm{O}$ atravessamento da cerca para coletar o coco, tendo as costas rasgadas pelos arames; o ato de escrever cartas de denúncias para as autoridades, a luta no conflito e a resistência na busca pelos direitos de permanecer na terra são expressões da "força" dessas mulheres.

Passando-se décadas de um capítulo sangrento da história e da geografia agrária brasileira, especialmente da região do Bico do Papagaio, o presente artigo pôs em relevo uma polifonia de vozes com ricas informações, muitas vezes ocultadas por agentes hegemônicos ligados ao capital. Os depoimentos permitem um movimento de resgaste da memória dos entrevistados e, por meio de suas narrativas, o reconhecimento e a valorização dos camponeses e camponesas que lutaram e continuam lutando por autonomia e liberdade no controle da terra e do território.

Conhecer essas diferentes experiências de luta e resistência pela terra, e na terra, é fundamental para entender o processo de conscientização política e as lutas mais recentes das famílias camponesas na região do Bico do Papagaio. 


\section{Agradecimentos}

O apoio financeiro do Conselho Nacional de Desenvolvimento Científico e Tecnológico $(\mathrm{CNPq})$; as orientações da Profa. Dra. Larissa Mies Bombardi, a leitura e apontamentos do Prof. Dr. Márcio Douglas Brito Amaral e da Profa. Dra. Rosa Elizabeth Acevedo Marin, além das considerações e sugestões de João Cleps Junior.

\section{Notas}

${ }^{1} \mathrm{O}$ presente texto deriva-se da tese de doutorado intitulada Reforma agrária e reconhecimento: o caminho da autonomia e liberdade das camponesas-quebradeiras de coco babaçu da região do Bico do Papagaio, defendida junto ao Programa de Pós-Graduação em Geografia Humana, no curso de Geografia, na Faculdade de Filosofia, Letras e Ciências Humanas, da Universidade de São Paulo, sob a orientação da Professora Dra. Larissa Mies Bombardi, no ano de 2018. A tese foi realizada com o apoio financeiro do Conselho Nacional de Desenvolvimento Científico e Tecnológico (CNPq).

${ }^{2}$ Considerando a realidade de conflito socioterritorial vivida pelas famílias entrevistadas, identificamos os depoimentos e povoados com as letras do alfabeto, entrevistado A, B, C..., e povoado A, B e C e D.

${ }^{3}$ Expressão usada pelas camponesas e camponeses ao se referirem às terras privadas.

${ }^{4} \mathrm{O}$ entrevistado A usa essa expressão para se referir à primeira área da formação dos seus "sítios".

${ }^{5}$ A situação de subordinação, exploração, luta e resistência dos camponeses do povoado A permaneceu até por volta do ano 2000. Os camponeses do povoado B foram os pioneiros no processo de ocupação das terras, porém foram cercados, muitos expulsos por fazendeiros e, atualmente, enfrentam tensões com a empresa de papel e celulose Suzano S.A., que se encontra na região. A realidade desses povoados será analisada em outro trabalho.

6 Os "centros" eram as áreas ocupadas pelos camponeses, onde criavam suas roças. Muitas vezes, localizavam-se distantes dos povoados onde residiam.

${ }^{7}$ Sistema identificado anteriormente como "agricultura migratória” por Andrade (2005).

${ }^{8}$ Por questões de segurança, optou-se por abreviar o nome da pessoa referida pela entrevistada $\mathrm{D}$, deixando apenas as suas iniciais.

${ }^{9}$ Essa é uma questão estudada por Oliveira (1991), a partir da teoria marxista. O autor ressalta que a questão fundamental nos estudos sobre a produção camponesa é a distinção do movimento na circulação entre esta e a produção capitalista. Na produção capitalista, tem-se, para definir seu movimento, a fórmula D-M-D na sua versão simples e D-M-D’ na sua versão normal, ampliada, portanto. Enquanto na produção camponesa, se está diante do movimento expresso na fórmula M-D-M. Por conseguinte, a lógica da produção camponesa está assentada na forma simples de circulação das mercadorias, onde se tem a conversão da mercadoria em dinheiro e a conversão do dinheiro em mercadoria, ou seja, vender para comprar. Logo, no ciclo M-D-M, a quantia de dinheiro que se obtém por meio da venda de uma mercadoria, vai ser consumida pela compra de outra mercadoria, em geral não produzida.

${ }^{10}$ Andrade (2005) analisa as estratégias de resistência das famílias das camponesas-quebradeiras de coco babaçu no estado do Maranhão e assevera que o mutirão era uma delas. Ressalta que, com a proibição dos fazendeiros ao acesso das famílias aos babaçuais, e o seu arrendamento, grupos de mulheres, homens e crianças se reuniram e "passaram a romper as cordas que sustentavam os chamados jacás, cestos carregados nos lombos dos animais, cheios de coco. Chegaram a queimar jacás e barracões. O clima de tensão se tornava cada dia mais agudo. Diante do avanço das famílias, em meados dos anos 1980, os proprietários, em represália, passaram a derrubar as palmeiras, inicialmente com machado e depois com máquinas. Nesse momento, a rebelião se espalhou, atingindo toda a região. Estava instalada a luta não apenas pelo acesso aos palmeirais, mas pela terra. Instaurava-se uma verdadeira guerra envolvendo, de um lado, as famílias camponesas e seus aliados, principalmente a Igreja Católica e, de outro, proprietários de terra, pistoleiros, vaqueiros, delegados de polícia, políticos" (ANDRADE, 2005, p. 179-179). 


\section{REFERÊNCIAS}

ALMEIDA, Alfredo Wagner Berno de. A ideologia da decadência: leitura antropológica a uma história de agricultura do Maranhão. Rio de Janeiro: Editora Casa 8/Fundação Universidade do Amazonas, 2008.

AMARAL FILHO, Jair do. A economia política do babaçu: um estudo da organização da extrato-indústria do babaçu no Maranhão e suas tendências. São Luís: SIOGE, 1990.

ANDRADE, Manuel Correia de. A terra e o homem no Nordeste: contribuição no estudo da questão agrária no Nordeste. 7. ed. São Paulo: Cortez, 2005.

ASSELIN, Victor. Grilagem: corrupção e violência em terras do Carajás. Petrópolis: Vozes, 1982.

BOMBARDI, Larissa Mies. Campesinato, luta de classes e reforma agrária (A Lei de Revisão Agrária em São Paulo). 2005. Tese (Doutorado em Geografia Humana) Departamento de Geografia, Faculdade de Filosofia, Letras e Ciências Humanas, Universidade de São Paulo, São Paulo, 2005.

. O Bairro Reforma Agrária e o processo de territorialização camponesa. São Paulo: Annablume, 2004.

CHAVES, Patrícia Rocha. Rebeldia e barbárie: conflitos socioterritoriais na região do Bico do Papagaio. 2015. Tese (Doutorado em Geografia Humana) - Departamento de Geografia, Faculdade de Filosofia, Letras e Ciências Humanas, Universidade de São Paulo, São Paulo, 2015.

FERNANDES, Bernardo Mançano. Movimentos socioterritoriais e movimentos socioespaciais: contribuição teórica para uma leitura geográfica dos movimentos sociais. Revista Nera, ano 8, p. 14-34, 2005.

HÉBETTE, Jean; MARIN, Rosa Acevedo. Colonização espontânea, política agrária e grupos sociais: reflexão sobre a colonização em torno da rodovia Belém-Brasília. In: HÉBETTE, Jean. Cruzando a fronteira: 30 anos de estudo do campesinato na Amazônia. Belém: EDUFPA, 2004. p. 41-73.

IANNI, Otávio. Colonização e contra-reforma agrária na Amazônia. Petrópolis: Vozes, 1979.

MARQUES, Marta Inez Medeiros. De sem-terra a "posseiro", a luta pela terra e a construção do território camponês no espaço da reforma agrária: o caso dos assentados nas fazendas Retiro e Velha-GO. 2000. Tese (Doutorado em Geografia Humana) Departamento de Geografia, Faculdade de Filosofia, Letras e Ciências Humanas, Universidade de São Paulo, São Paulo, 2000.

O modo de vida camponês sertanejo e sua territorialidade no tempo das grandes fazendas e nos dias de hoje em Ribeira-PB. 1994. Dissertação (Mestrado em Geografia Humana) - Departamento de Geografia, Faculdade de Filosofia, Letras e Ciências Humanas, Universidade de São Paulo, São Paulo, 1994. 
MARTINS, José de Sousa. Fronteira: a degradação do outro nos confins do humano. São Paulo: Contexto, 2009.

. A sociedade vista do abismo: novos estudos sobre exclusão, pobreza e classes sociais. Petrópolis: Vozes, 2002.

. A chegada do estranho. São Paulo: Hucitec, 1993.

. Caminhada no chão da noite: emancipação política e libertação nos movimentos sociais no campo. São Paulo: Hucitec, 1989.

. Camponeses e a política no Brasil. Petrópolis: Vozes, 1986.

. A militarização da questão agrária. Terra e poder: o problema da terra na crise política. 2. ed. Petrópolis: Vozes, 1985.

OLIVEIRA, Ariovaldo Umbelino. A geografia agrária e as transformações territoriais recentes no campo brasileiro. In: CARLOS, Ana Fani Alessandri (Org.). Novos caminhos da geografia. 6. ed. São Paulo: Contexto, 2013. p. 63-110.

. O Marxismo, a questão agrária e os conflitos pela terra no Pontal do Paranapanema. In: COGGIOLA, Osvaldo (Org.). Marx e Engels na história. São Paulo: Xamã, 1996. p. 157-167.

. A agricultura camponesa no Brasil. São Paulo: Contexto, 1991.

SADER, Maria Regina C. de Toledo. Migração e violência: o caso da pré-Amazônia Maranhense. Revista Terra Livre. n. 6, p. 65-76, 1989. Disponível em: <http://www.agb.org.br/publicacoes/index.php/terralivre/article/view/76>. Acesso em 30 maio 2019.

. Espaço e luta no Bico do Papagaio. 1986. Tese (Doutorado em Geografia Humana) - Departamento de Geografia, Faculdade de Filosofia, Letras e Ciências Humanas, Universidade de São Paulo, São Paulo, 1986.

SANTOS, José Vicente. Tavares. Colonos do vinho: estudo sobre a subordinação do trabalho camponês ao capital. São Paulo: Hucitec, 1978.

VALVERDE, Orlando. A rodovia Belém-Brasília: estudo de Geografia Regional. Rio de Janeiro: IBGE, 1967.

VELHO, Otávio Guilherme. Frente de expansão e estrutura agrária: estudo do processo de penetração numa área da Transamazônica. 3. ed. Manaus: UEA Edições, 2013.

Recebido em 01/12/2018.

Aceito para publicação em 23/08/2019. 